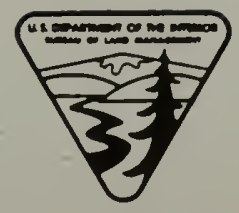

\title{
Watchable Wildlife Strategy for California Desert District
}

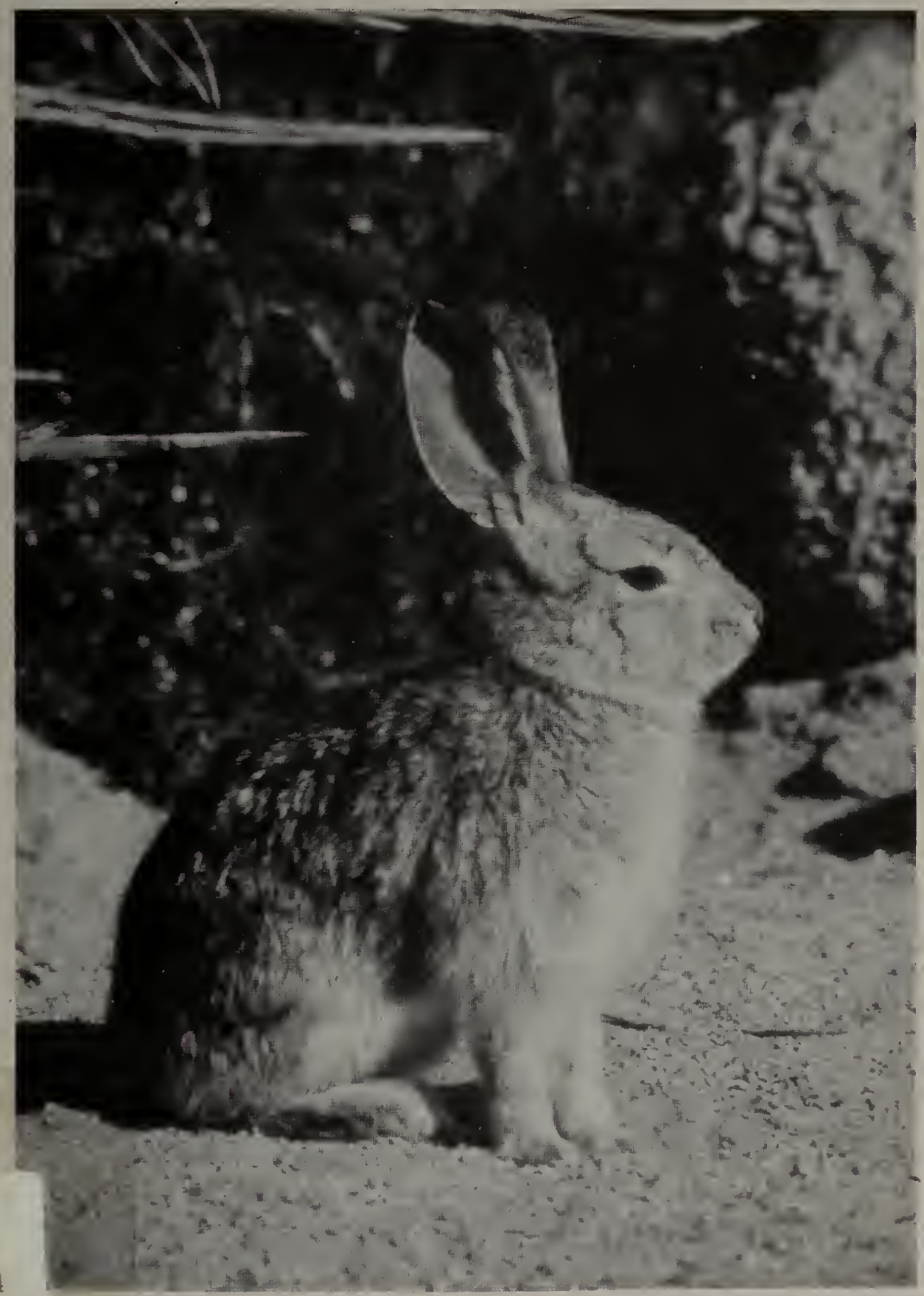

California Desert District Fish \& Wildife 2000 Series

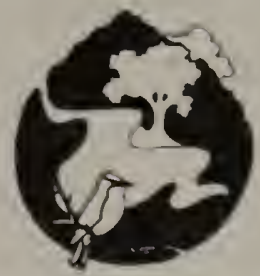


3LM LIBRAFY

SC-653, BLDG. 50 CENTER

DENVER FEDERA 25047

DENVER FE 25047
P.O. BOX, CO 802250047
DENVER,

BLM/CA/PT-94/007+6500 


\title{
WATCHABLE WILDLIFE
}

\section{STRATEGY FOR}

\section{CALIFORNIA DESERT DISTRICT}

Prepared by

\section{CALIFORNIA DESERT DISTRICT}

\author{
BUREAU OF LAND MANAGEMENT
}





\title{
APPROVAL PAGE
}

\section{WATCHABLE WILDLIFE}

\author{
STRATEGY FOR
}

\section{CALIFORNIA DESERT DISTRICT}

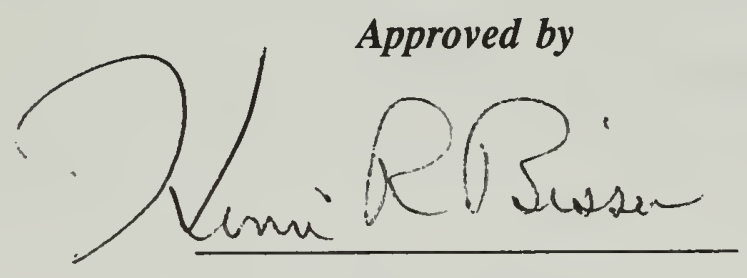

District Manager,

California Desert District, Bureau of Land Management

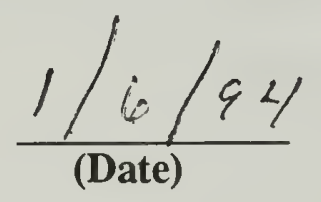

(Date) 


\section{CONTENTS}

Section

Page

Title Page

Approval Page

Contents

INTRODUCTION

GOALS OF CALIFORNIA DESERT DISTRICT

WATCHABLE WILDLIFE PROGRAM

POLICY GUIDELINES AND STANDARDS

IDENTIFICATION OF WATCHABLE WILDLIFE VIEWING SITES

Definition of Viewing Site

Criteria for Designating Viewing Site

List of Approved Sites in California Desert District

Description of Key Wildlife at Each Viewing Site

WILDLIFE VIEWING SITE ENHANCEMENT

Site Enhancement Team

Enhancement Actions

PROGRAM COORDINATION

FUNDING REQUIREMENTS 


\section{INTRODUCTION}

The Watchable Wildlife Program is intended to establish "a viewing network [which] includes land and facilities that are especially well-suited for observing wild animals in natural or modified environments. It also includes the associated efforts to provide educational and interpretive information to viewers, and to encourage their active involvement in wildlife conservation." (Vickerman 1991)

In "Watchable Wildlife: A National Initiative", Vickerman (1991) gave the following definition which combines the recreational, educational, and conservation themes:

"All wildlife is watchable. A Watchable Wildlife program should:

- provide enhanced opportunities for people to experience wildlife;

- promote learning about wildlife and its needs; and

- lead to active support of conservation."

In December 1990, the heads of nine Federal agencies in three Departments and the representatives of five conservation agencies signed a Memorandum of Understanding "to provide a framework for cooperative activities necessary to develop, implement, maintain, and enhance a Watchable Wildlife Program on Federal and State lands, and to assist private landowners." (MOU 1990) Signatories to the MOU included the Director of the Bureau of Land Management (BLM). As stated in the MOU, "The parties agree that increased effort should be made to: identify and publicize wildlife viewing opportunities on Federal lands; cooperate in providing facilities; provide interpretation of wildlife biology and management; and ensure access to such sites, where activities are not harmful to wildlife or other resources."

In April 1992, the BLM issued its Watchable Wildlife Strategic Plan (BLM 1992). The plan identified National BLM goals, objectives, and recommended actions for implementing the Watchable Wildlife Initiative.

The purpose of this Watchable Wildlife strategy is 1) to establish a formal list of Watchable Wildlife viewing sites in the California Desert District, 2) to set forth the initial actions necessary to enhance the viewing sites sufficient that the purposes of the program are met, and 3) to set forth the standards and policies guiding management of viewing sites. The identification of enhancement actions will promote the establishment of priorities for and among the viewing sites so that energies and funds might be directed most efficiently. The District strategy will also aid in development of the overall program by listing various cooperating agencies and organizations which can assist. Site specific plans and environmental assessments will be completed for each viewing area. 


\section{GOALS OF CALIFORNIA DESERT DISTRICT WATCHABLE WILDLIFE PROGRAM}

- Develop policies and standards for the development of a thorough and consistent Watchable Wildlife program.

- Identify Watchable Wildlife viewing sites in California Desert District.

Publicize the availability of special opportunities provided by the California Desert District viewing sites.

- Develop and distribute interpretive and educational materials and themes to enhance the recreational, educational, and conservation value of the viewing sites.

- Ensure that adequate access to the viewing sites is available.

- Provide facilities that will enhance the public viewing capability.

Develop communication and cooperation between government and non-government entities that will aid in accomplishing the other goals. 


\section{POLICY GUIDELINES AND STANDARDS}

Following are the guidelines and standards which will direct the Watchable Wildlife Program in the California Desert District. Most of these are derived from National program standards.

1. The criteria for designating a Watchable Wildlife viewing site are given in the next section.

2. Visitor safety shall be a strong consideration in the design of all facilities.

3. Facilities shall be constructed in accordance with accessibility requirements specified in "Uniform Federal Accessibility Standards" (FED-STD-795) to facilitate use by the physically handicapped and elderly to the extent possible. Further guidance specific to recreation facilities can be found in the "Design Guide for Accessible Outdoor Recreation" (Interim Draft) prepared by a USDA Forest Service and USDI National Park Service task group.

4. Visitor use shall be managed to minimize degradation of resources or conflicts with other uses. In particular, disturbance to sensitive wildlife species and cultural and historic resources shall be minimized.

5. Each viewing site shall be signed with the Watchable Wildlife Standard Directional Signs according to the specifications in "Watchable Wildlife: A National Initiative (Vickerman 1991; pp. 59-62). Other signs shall be designed and constructed according to BLM and District policies.

6. Interpretive trails shall be developed with specific "themes" or messages. Trails shall begin with a provocative and professional trailhead sign that identifies the trailhead, the trail theme, and the managing agencies. The visitor shall be informed of the walking time and distance, terrain difficulties, and other pertinent rules. Visitor resting shall be considered in the trail design. The placement of trail signs, facilities, and other interpretive materials shall be developed using professional guidelines.

7. All publications, such as Viewing Site Guides, trail guides, and bird checklists, shall comply with BLM publications standards and policies. These are set forth in BLM Manual H-1553 ("Graphic Arts"). In addition, District publication standards shall be followed (currently Instruction Memorandum CDD-92-47). 


\section{IDENTIFICATION OF WATCHABLE WILDLIFE VIEWING SITES}

\section{Definition of Viewing Site}

For the purposes of the Watchable Wildlife Program in the California Desert District, a viewing site is defined as

"An area where 1) the wildlife is available and well-suited for viewing and 2) there is an opportunity to promote viewing use, learning about wildlife, or involvement in wildlife conservation."

In the Watchable Wildlife Strategic Plan (BLM 1992), a viewing site, as defined above, is called a "viewing area" as distinct from a "viewing site" which is a particular location in the viewing area where there is a good opportunity for viewing wildlife.

\section{Criteria for Designating Viewing Site}

Wildlife viewing sites may vary widely. Sites may be less than an acre to several thousand acres in size. The primary viewing opportunities may occur seasonally or year-round. The viewing effort can be effortless to challenging. However, there are a series of standards which each area must meet to qualify as a potential wildlife viewing site. Following is a list of the specific criteria:

1. The site must have reasonably safe access to the public by passenger car or on foot for a short distance.

2. Visitors to the site must have a reasonably good chance of seeing the wildlife whose viewing is being promoted during the proper season. The wildlife whose viewing is being promoted should be species or groups which are out of the ordinary in their abundance at the site, in their overall rarity (but still viewable at the site), in their uniqueness in the area, or in their interpretive value.

3. The wildlife species or group(s) of interest must be native and free-roaming.

4. The site must be manageable such that visitor use does not damage habitat or disturb wildlife. 
5. The scenic quality must be good, avoiding sewage ponds, landfills, and other places which might be objectionable to the public.

6. The site must be free of uses which will result in a direct conflict with wildlife viewing. For example, an off-highway vehicle area nearby may create noise conflicts for the viewers.

7. Site designation and enhancement must have the cooperation and consent of any landowners which might be directly involved or affected. Access to the site must also be agreeable to those owning the legal access.

8. The District must be willing to make a special commitment to the wildlife viewing use at the site. In other words, some viewing enhancement or visitor accommodations are expected to be made.

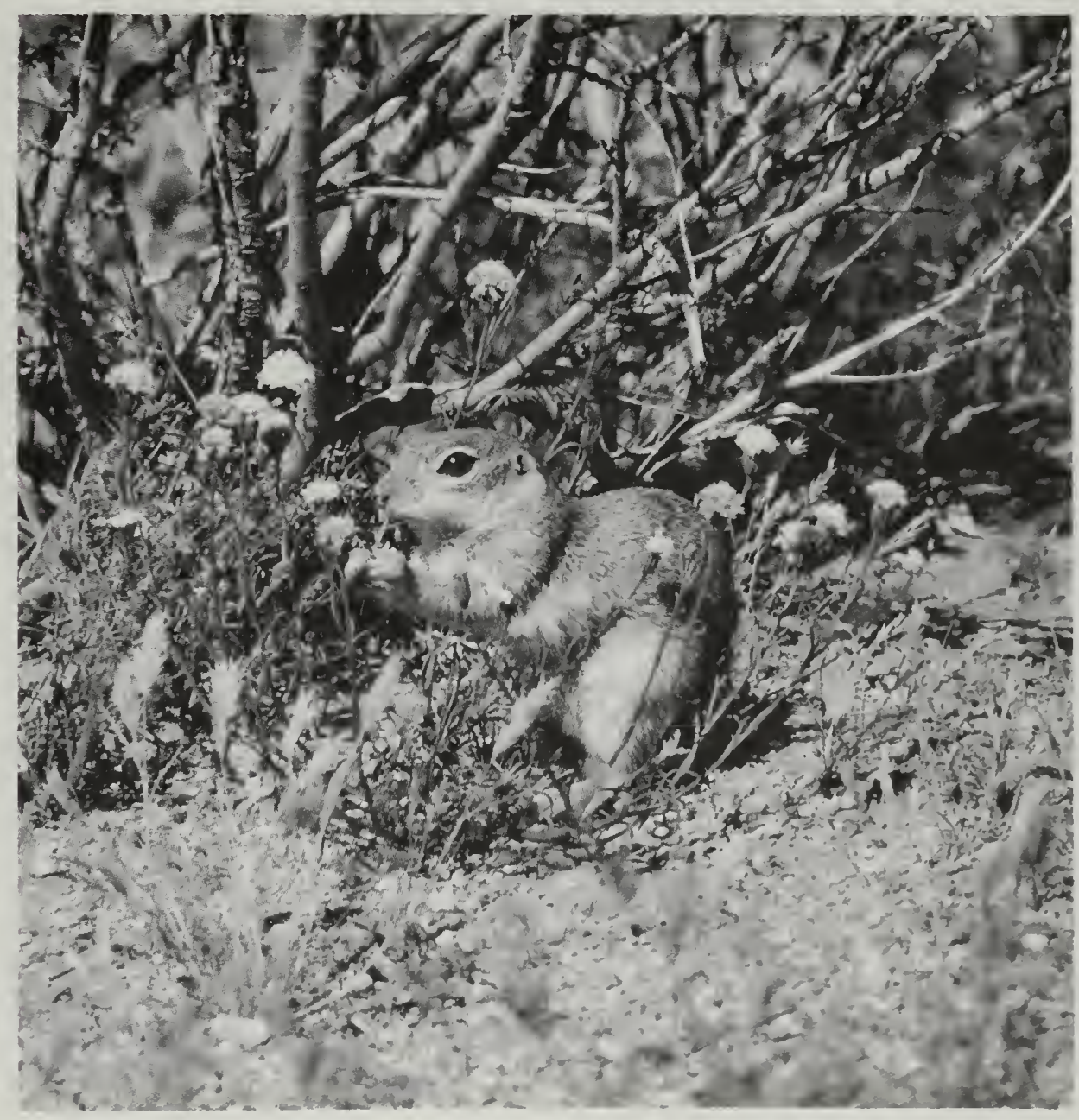




\section{List of Approved Viewing Sites in California Desert District}

Based on the designation criteria presented in the previous section, the following areas are designated as "Watchable Wildlife viewing sites":

\begin{tabular}{c} 
Afton Canyon \\
Algodones Dunes - Osborne Overlook \\
Amargosa Canyon \\
Big Morongo Preserve \\
Coachella valley Preserve \\
Desert Tortoise Natural Area \\
Dos Palmas Reserve \\
Grimshaw Lake and Marsh \\
Harper Dry Lake and Marsh \\
Soda Springs \\
\hline
\end{tabular}

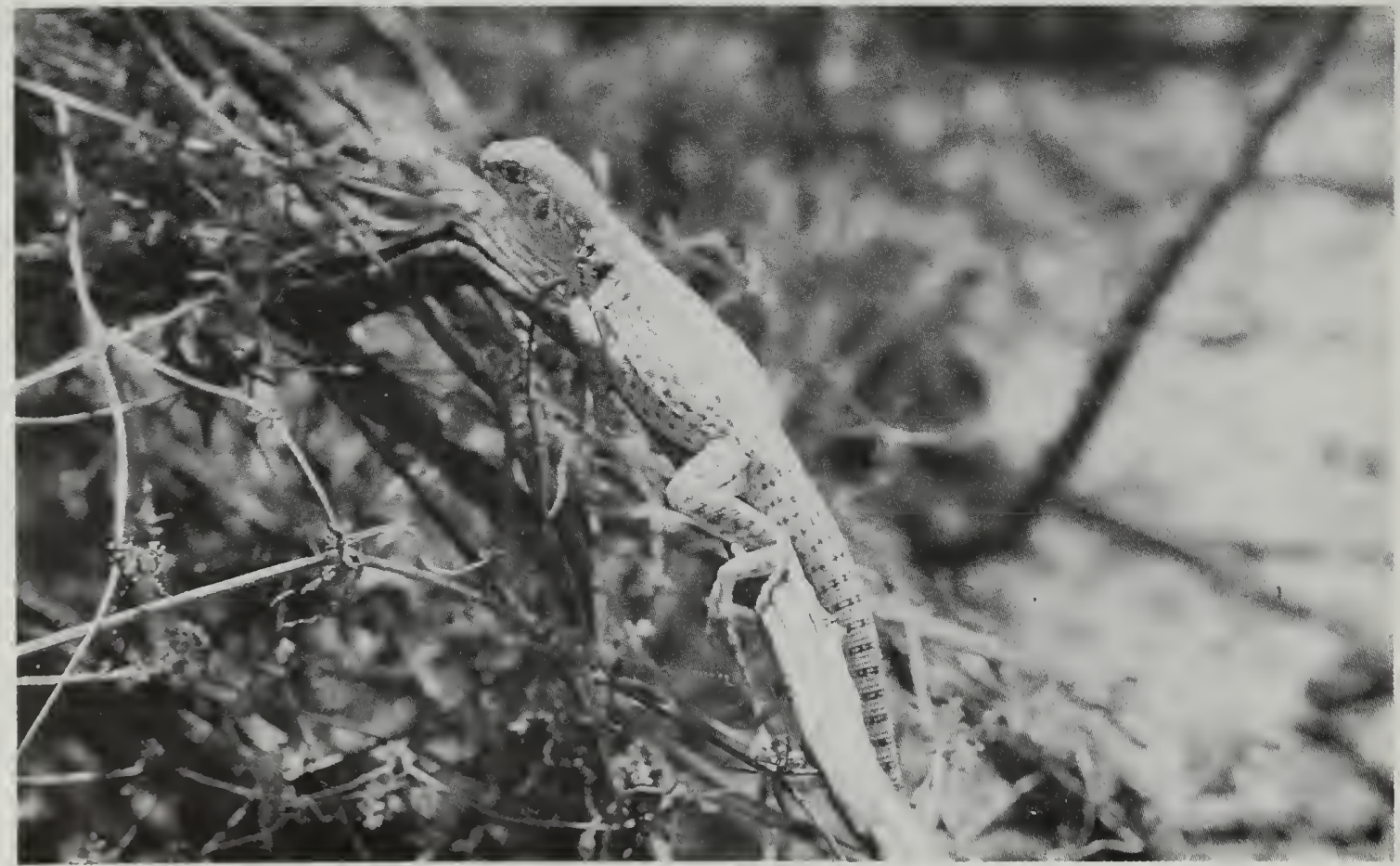




\section{Description of Key Wildlife at Each Viewing Site}

\section{Afton Canyon}

Key wildlife: Riparian songbirds, marshbirds, waterfowl, raptors, bighorn sheep, lizards, southwestern pond turtle, bullfrogs.

Description of viewing opportunities: Afton Canyon was formed where the Mojave River flows through a small mountain mass which is generally impervious and of lower erodability than the surrounding area. This results in the formation of a canyon which narrows as the river flows eastward. It also results in the river flowing above ground for a short distance.

The resulting surface flow has created a marsh habitat with interspersed open water. Surrounding woodlands are now composed primarily of exotic tamarisk trees. Before 1960, woodland trees were primarily cottonwood and willow. Adjacent hillsides are typical desert scrub.

The riparian and marsh vegetation attracts many riparian species in all seasons, but especially during spring and fall migration when the site provides a lush stopover for songbirds, shorebirds, and marshbirds. The surrounding mountains provide nesting and foraging habitat for many species of raptors, such as prairie falcons, golden eagles, and red-tailed hawks. These and other raptors, such as northern harriers, are attracted to the abundant prey found in the canyon.

Hybrids of the endangered Mohave chub and the arroyo chub, which is common in coastal regions, occur in this section of the river. Other exotic fish such as brown bullhead, channel catfish, and sunfish are found in the river. Southwestern pond turtles are found only here and at two other sites further upstream in the desert.

Bighorn sheep, found mainly in the Cady Mountains to the south, regularly come down the slopes of the canyon to drink from the river.

The best viewing seasons are the spring and fall when temperatures are moderate and migrant birds are present.

\section{Algodones Dunes - Osborne Overlook}

Key wildlife: Lizards, snakes, songbirds.

Description of viewing opportunities: The Algodones (Imperial) Dunes are the largest sand dune system in California. Osborne Overlook, located near the outpost of Glamis, is a large, paved turnout on Highway 78 approximately 22 miles east of Brawley. The overlook provides a panoramic view of the northern dunes, adjacent lowlands, and distant Chocolate Mountains. The scenic view and large parking area attract highway travelers and off-highway vehicle recreationists to the overlook. The existing facilities and high seasonal visitor use provide an excellent opportunity to interpret wildlife in the nearby sand dune ecosystem and associated microphyll woodlands. 
Osborne Overlook is located on the south side of Highway 78 in an off-highway vehicle open area. A short walk to the north, across Highway 78, affords the visitor an opportunity to enter one of BLM's Research Natural Area. Motor vehicle use was excluded from the northern dunes with the establishment of the Research Natural Area in 1972. These active dune comprise an example of a dynamic sand dune ecosystem which harbors abundant wildlife. Tracks and burrows of beetles, lizards, snakes, kangaroo rats, coyotes, and others provide an intriguing and challenging storyboard for the visitor. Colorado Desert fringe-toed lizards, which are abundant on these northern dunes, have numerous, highly specialized adaptations for sand dune life and regularly surprise visitors as they bound from the sand and scurry for burrow or cover.

About 5 miles to the east on Highway 78 and northward along a graded dirt road, numerous large washes lead westward from the Chocolate Mountains. These washes terminate at the higher dunes, where the occasional water flow pools and forms pockets of microphyll woodland. Trees supported in these pockets include palo verde, honey and screwbean mesquite, and ironwood. These woodlands provide an overstory for a seasonal abundance of songbirds and other wildlife, which use the washes as shady travel corridors. Desert hikers (the area is closed to vehicles) will enjoy the same corridors while exploring these microphyll pockets. Mammals such as black-tailed jackrabbits and burro deer can often be observed using these washes. The area supports several sensitive plant and animal species found nowhere else.

Viewing is good in all seasons; however, lizards and snakes are most active in the warmer months. In summer, daytime temperatures are very hot; so viewing is best in the evenings or mornings. Birdwatching is seasonally best in spring during the mornings or evenings. Spring is also excellent for wildflower viewing. Wildlife in the dunes is very active at night, except in winter when temperatures can drop near freezing.

Interpretive facilities will be limited to the overlook and roadways as the viewing areas are within a region currently being considered for Wilderness designation by Congress.

\section{Amargosa Canyon}

Key wildlife: Riparian songbirds (including endangered least Bell's vireo), raptors, lizards, desert fishes.

Description of viewing opportunities: Amargosa Canyon was formed where the Amargosa River passes through the Sperry Hills on its way to Death Valley. The river flows underground for much of its length but rises above ground in Amargosa Canyon and for some distance above and below. The viewing site is located in the northern portion of the canyon, immediately south of the Old Spanish Trail Highway just east of the town of Tecopa. Viewing and hiking opportunities are good throughout the Canyon.

The year-round surface flow provides a stable stream habitat for several species of fish, including the Amargosa pupfish and Nevada speckled dace.

The river is intermittently lined with riparian woodlands consisting valley willow, wild grape, and tamarisk interspersed with small, linear marshes of cattail, bulrush, and saltgrass. This rich riparian and marsh complex provides habitat for a variety of songbirds in all seasons, but viewing opportunities are best in the spring and fall when migrant songbirds use the area for resting and watering. Swallows, swifts, and various raptors, such as golden eagles, prairie falcons, and red-tailed hawks, use the 
surrounding hills and cliffs for nesting in the spring. A few raptors also use the hills and cliffs for roosting in the winter.

Pockets of marsh provide habitat for the endangered Amargosa vole and Amargosa southern pocket gopher. The Amargosa vole is a subspecies of California vole found only along the Amargosa River in the canyon and at Grimshaw Marsh just to the north. Although both are diumal rodents, they travel primarily along runways below the grassy cover. Sandpipers may be seen along the watercourse especially in winter, early spring, and fall.

Resident lizards and snakes are plentiful year-round but are most active during the warmer months from April through October.

\section{Big Morongo Preserve}

Key wildlife: Riparian songbirds, woodpeckers, hummingbirds, raptors, lizards.

Description of viewing opportunities: Big Morongo Preserve is a dense cottonwood and willow woodland along a perennial stream flowing about 3 miles through Big Morongo Canyon. The dense understory and high canopy provide habitat for a wide diversity of birds and reptiles. Due to the watercourse, the adjacent uplands also support an unusual abundance of birds. The high diversity is partially a consequence of the canyon providing an important ecotonal connection between the Mojave Desert to the north and the Colorado Desert to the south.

The abundance of water, vegetation, and prey provide essential habitat elements for more species of mammals than most other desert areas. Among these mammals are Nelson's bighorn sheep, coyotes, bobcats, foxes, skunks, and raccoons, as well as many kinds of rodents.

Various portions of the site are presently owned and managed cooperatively by the County of San Bernardino, the Nature Conservancy, and the BLM. Primary access to the site is from the town of Morongo Valley on Highway 62. Developed trails and boardwalks provide access through a major portion of the area. Interpretive displays and facilities enhance the visitor's experience.

Birdwatching is excellent in all seasons. Spring and fall migrations are especially good for the desert. Breeding birds in the spring are especially unusual for southern California deserts; among the notable species are summer tanager, vermilion flycatcher, and Bell's vireo.

\section{Coachella Valley Preserve}

Key wildlife: Coachella Valley fringe-toed lizard, other lizards and snakes, desert songbirds, raptors, desert pupfish.

Description of viewing opportunities: The Coachella Valley Preserve encompasses about 13,000 acres of Colorado Desert shrubland, dunes, mudhills, and palm oases in the Coachella Valley. These highly varied habitats support a variety of common desert snakes, lizards, rodents, and songbirds, as well as 
several rare, specialized animals. Among the latter are the threatened Coachella Valley fringe-toed lizard, which is restricted to fine "blowsand" dunes in the Coachella Valley.

A series of palm oases along the San Andreas Fault provide important habitat for songbirds, kestrels, and other birds especially during spring and fall migration. Thousand Palms Oasis has been developed for visitors and is a focal point of the interpretive program. The endangered desert pupfish has been introduced here into artificial ponds.

The desert shrublands and interspersed dunes support good populations of such common lizards as desert iguana, leopard lizard, and zebra-tailed lizard. Common birds in these habitats include cactus wren, verdin, phainopepla, and Costa's hummingbird. Prairie falcons nest within the Preserve in the cliffs in the Indio Hills and forage widely throughout the area.

The best viewing season is the spring when temperatures are moderate and wildlife is most active. Winters are also very mild, and wintering birds are abundant. Reptile activity is reduced in the winter to the warmer times of day.

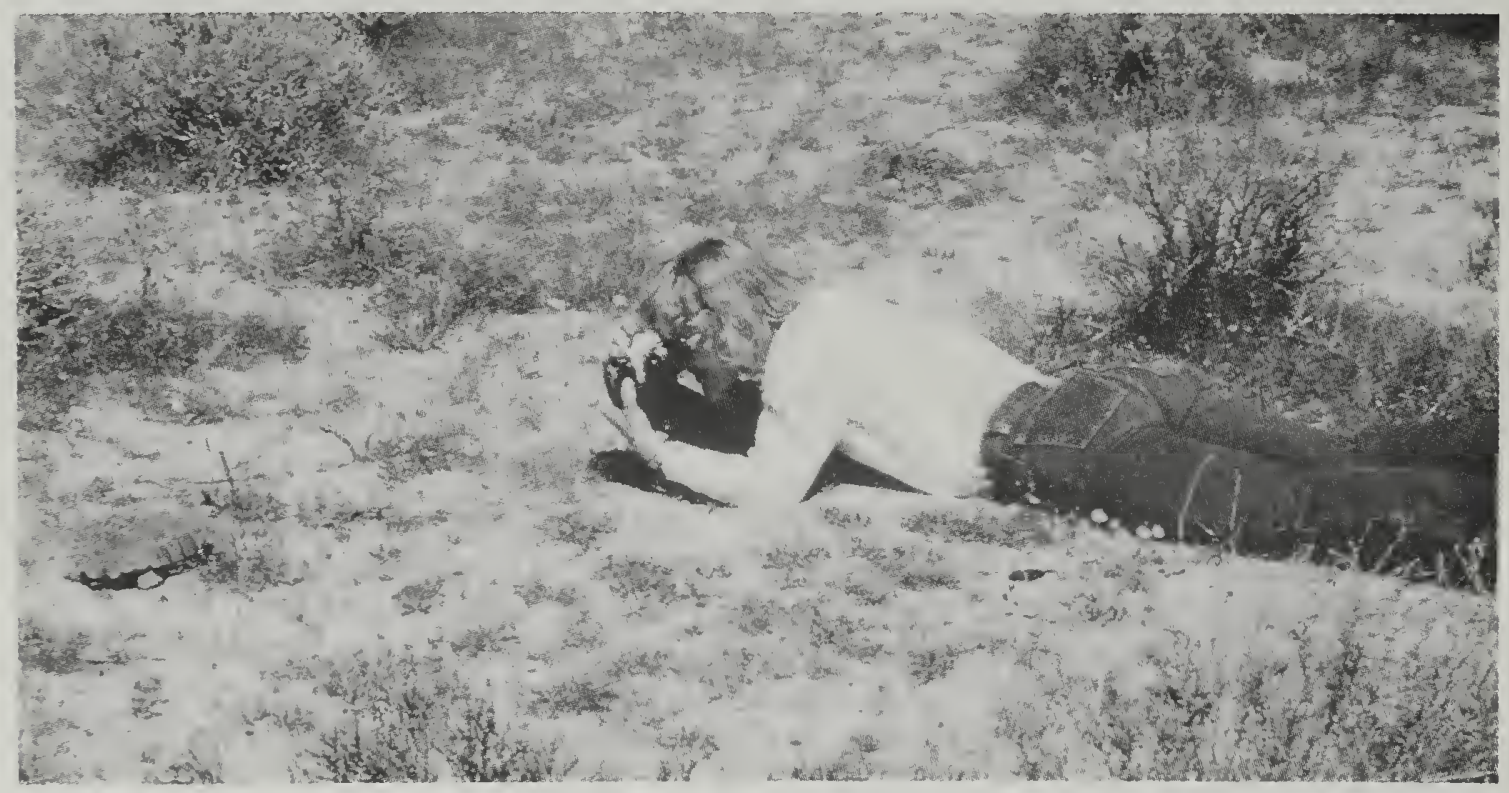

\section{Desert Tortoise Natural Area}

Key wildlife: Desert tortoise, desert songbirds, lizards, snakes, rabbits, ground squirrels.

Description of viewing opportunities: The Desert Tortoise Natural Area ia a 28,000 -acre preserve in the western Mojave Desert a few miles north of California City. The preserve is comprised primarily of desert scrub habitat dominated by creosotebush and burro bush.

The area was set aside mainly to protect a population of the threatened desert tortoise. Desert tortoises are mostly out and moving about in the spring and early fall. Other reptiles, such as zebra-tailed lizards, 
leopard lizards, western whiptails, and sidewinders, are commonly observed when temperature are not unduly hot or cold.

The area also supports populations of Mohave ground squirrel. This species, its cousin the white-tailed antelope ground squirrel, and rabbits and hares are active throughout much of the day in the spring and fall.

Best wildlife viewing is in the spring when songbirds, ground squirrels, rabbits, lizards, snakes, and tortoises are actively feeding, courting, and moving about. Viewing is best in the morning hours before temperatures rise too high. An interpretive center on the southeastern corner of the preserve is the focus of wildlife viewing. The center includes a covered interpretive kiosk, interpretive trail, restrooms, and parking lot. An interpretive naturalist has been stationed here in the spring of some years to assist and educate visitors.

\section{Dos Palmas Reserve}

Key wildlife: Rails and other marshbirds, waterfowl, desert songbirds, lizards, desert pupfish.

Description of viewing opportunities: Dos Palmas Reserve is a large wildlife preserve of over 20,000 acres. The reserve includes many palm oases, a perennial flowing stream, a brackish water estuary, and surrounding uplands of desert scrub and dunes.

The focal point of management is at the Dos Palmas Ranch. This area has an extensive array of artificial impoundments fed by an artesian spring originating at the Dos Palmas Oasis. These ponds provide a varied mix of marsh vegetation and open water which is used by egrets, herons, rails, coots, ducks, kingfishers, killdeer and other shorebirds, marsh wrens, red-winged blackbirds, and various other marshdependent birds. The ponds are now inhabited by various species of carp, bass, tilapia, catfish, and sunfish. However, the intent is to eliminate these exotic species and introduce desert pupfish, an endangered fish native to the Salton Sink.

The palm oases provide a dense overstory used by a variety of birds and mammals. Surrounding areas with a high watertable support extensive mesquite hummocks, which are rich in songbirds such as phainopeplas, Abert's towhees, verdins, and black-tailed gnatcatchers.

Salt Creek serves as a marsh and aquatic corridor between several of the palm oases and the Salton Sea. Salt Creek forms a brackish water estuary where it empties into the Salton Sea. The associated marsh vegetation supports rails, herons, egrets, marsh wrens, and many other species. The open water area of the estuary is used by numerous species of gulls, terns, ducks, and grebes.

Wildlife viewing is excellent year-round. The Salton Sink is a major wintering area for many bird species. In addition, the Coachella Valley-Salton Sink-Gulf of California rift valley forms a secondary route on the Pacific flyway. Hence, birds of many groups, including raptors, shorebirds, songbirds, and waterfowl, are abundant during spring and fall migration. The high productivity associated within permanent wetlands and perennial streams makes birdwatching opportunities good during the spring breeding season as well. In the summer, species abundance is high, but high temperatures make viewing uncomfortable. As a result, summer viewing is best done in the very early morning hours. 


\section{Grimshaw Lake and Marsh}

Key wildlife: Marshbirds, waterfowl, Amargosa vole, Amargosa southern pocket gopher, native fishes, frogs and toads.

Description of viewing opportunities: Grimshaw Lake, located along the Amargosa River near Tecopa, is composed of several small ponds and interconnecting marshlands. Numerous springs and unusual seepholes are scattered throughout the area, providing habitat for a variety of frogs and toads. The lake and marsh lie in the lakebed of ancient Lake Tecopa which occupied the area until it naturally drained in prehistoric times.

The Grimshaw Marsh complex contains large patches of rushes, bulrushes, cattails, and saltgrass. This dense vegetative cover provides habitat for numerous marshbirds such as coots, herons, egrets, and rails. Grimshaw Lake and the small ponds distributed throughout the marsh are home to waterfowl such as cinnamon teal, mallards, and other ducks and geese, especially during spring and fall migration. Northern harriers hunt low over the marshy areas.

The marshes provide habitat for the endangered Amargosa vole and Amargosa southern pocket gopher. These small, diurnal rodents are out and about during the day but are seldom observed because they move about along runways beneath the dense vegetation. However, runways and food caches in "haystacks" can be seen year-round.

Several species of native fishes can be viewed in hot and cold springs scattered about Grimshaw Marsh and the surrounding uplands, especially east of Tecopa Hot Springs Road.

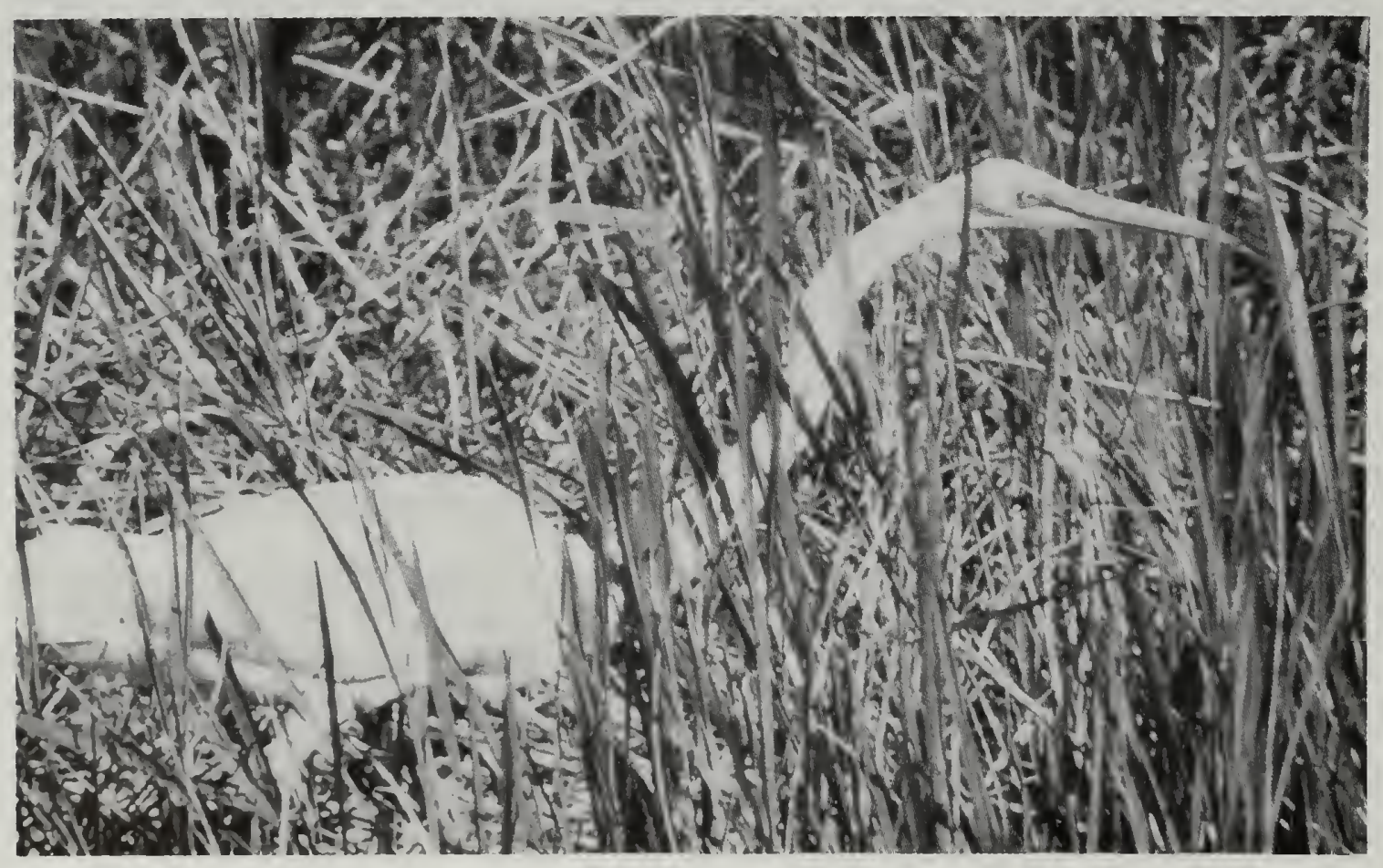




\section{Harper Dry Lake and Marsh}

Key wildlife: Raptors, marshbirds, waterfowl, shorebirds.

Description of viewing opportunities: Harper Dry Lake is located about 25 miles west of Barstow in the western Mojave Desert. The lakebed is dry most of the year, but intermittent moisture promotes production of invertebrates, especially around the lake margins. These invertebrates are an essential food source for sandpipers and plovers. This group of birds is especially abundant during winter, but numbers are also good during spring and fall migrations. Waterfowl can be found in isolated open waters within the marshlands and on the lakebed in years of abundant rainfall.

Extensive bulrush and cattail marshes surround the lake. These marshes are partially sustained by runoff from nearby agricultural fields. The dense marsh vegetation provides good habitat for marsh wrens, rails, short-eared owls, and northern harriers. The latter two feed primarily on small rodents found throughout the marsh. Many other raptor species feed in the marsh and surrounding uplands. Mesquite bosques in the vicinity support loggerhead shrikes and long-eared owls. Best viewing of marsh wildlife is in the winter when raptors and marshbirds are most abundant.

\section{Soda Springs}

Key wildlife: Mohave tui chub, Saratoga Springs pupfish, desert songbirds, lizards, snakes.

Description of viewing opportunities: Soda Springs lies along the western shore of Soda Dry Lake just south of the town of Baker. The area has a weil developed research/education center operated by the Desert Studies Consortium, a cooperative venture of seven California universities. Derived from the remains of a nineteenth century fort and subsequently a health resort, the facilities have a high historic significance.

Biologically, the major features of the area include two small ponds and a spring-fed pool which contain populations of Mohave tui chub and Saratoga Springs pupfish. The former is an endangered species, and the latter is found at only a few locales in the Death Valley region. Both species are readily visible at one of these ponds and the spring. The remaining pond has been landscaped to provide habitat for waterfowl, wading and perching birds, as well as the southwestern pond turtle.

The facility has been landscaped in the last fifty years with exotic species, primarily tamarisk, palms, and oleander. This exotic vegetation has low wildlife value despite its apparent lushness. Nearby and along the western shore of the lakebed are small patches of marsh made up primarily of bulrushes, cattails, and saltgrass. These small marshes and the landscape plantings provide some shelter for birds and mammals. As a result, birdwatching is better than most desert shrubland, and occasionally uncommon desert birds are present in low numbers.

Lizards and snakes common to both the eastern and western Mojave Desert are present in good numbers in the surrounding uplands. Fish can be viewed any time of the year, but fish activity is highest in spring and summer. Bird populations are best in winter and during spring migration. The site has a full-time caretaker, a short self-guided trail, and a large kiosk with restrooms. Natural history research projects occur in the area year-round. 


\section{WILDLIFE VIEWING SITE ENHANCEMENT}

\section{Site Enhancement Team}

Each Watchable Wildlife viewing site shall have a site enhancement team composed of a wildlife biologist and an interpretive specialist. Other team members might include a recreation specialist, botanist, external affairs officer, landscape architect, and engineer. Members of the public (e.g., physically challenged representative) might also be invited to participate on the team. The team should have a designated team lead. The team will prepare the site enhancement plan and environmental assessment.

\section{Enhancement Actions}

Following are lists of proposed and existing viewing enhancements for the designated viewing sites. Site enhancements include only those which will 1) enhance viewing of wildlife, 2) aid visitors in the understanding or appreciation of wildlife, or 3) provide needed facilities for visitors. Site enhancements which will promote wildlife populations are not included; these measures are found in site-specific activity plans (e.g., habitat management plans, plans for Areas of Critical Environmental Concern). Generally, these measures are based on objectives for wildlife management rather than wildlife viewing.

The proposed enhancements for each site have been based upon the wildlife available, the type of wildlife which is expected to be of viewing interest, the accessibility of the site, and the availability of existing facilities. All identified enhancements are preliminary and are based upon incomplete evaluations of wildlife, potential users, interpretive opportunities, and visitor management capabilities. The final design and placement of enhancements will be based upon site enhancement plans which shall be developed later for each site. These plans shall include environmental review.

All enhancements shall be designed to protect wildlife from undue disturbance. Where especially sensitive or rare wildlife occurs, extra consideration shall be given. Site enhancement plans should incorporate the principles and guidelines described in the enhancement guidebook entitled "Nature Watch" (Hudson 1992).

All sites are accessible by passenger vehicle. Regular road maintenance may be required for some sites. All sites have parking available. Many sites contain some 
type of trash receptacle. Visitors will be encouraged to pack trash out with them. Trash receptacles are not considered essential at remote sites, where the number of visitors is expected to be low to moderate.

Each site shall have the standard highway and roadway directional signing as described in the section discussing "Policy Guidelines and Standards." "Interpretive Signing" is meant to include all signs which direct visitor use, explain the features and management practices at the site, or present wildlife information and interpretation. A "Picnicking Area" shall include one or more tables and perhaps a cover for shade.

Viewing Site Guides will be single page. They will provide information on facilities available and interpretation of the wildlife resources.

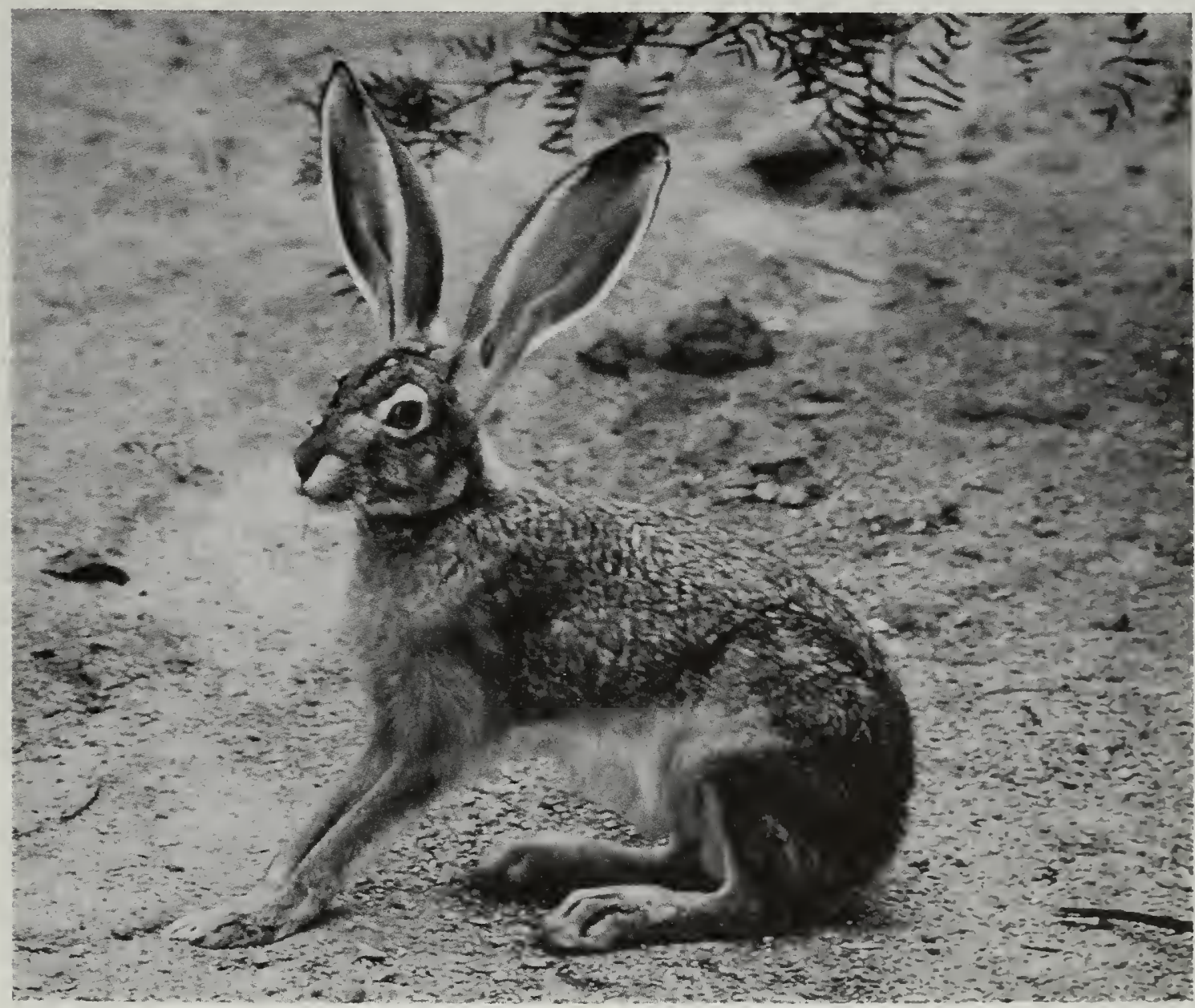




\section{AFTON CANYON \\ VIEWING SITE}

Viewing Site Guide

Existing

Proposed

Bird Checklist
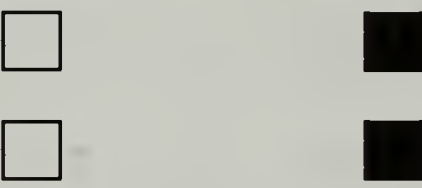

Included in "State Viewing Guide"
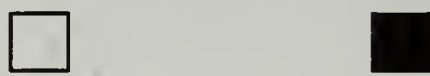

Highway/Roadway Directional Signing
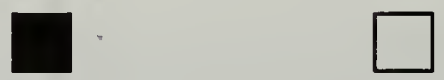

Entrance Sign
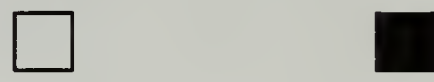

Interpretive Signing
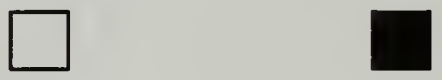

Kiosk
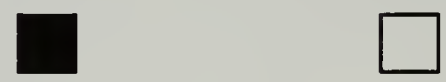

Interpretive Trail
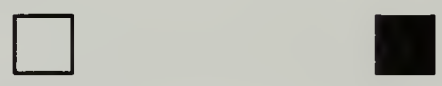

Restrooms

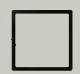

Camping Sites

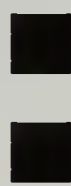

$\square$

Potable Water

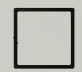

Picnicking Area

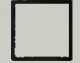




\section{ALGODONES DUNES - OSBORNE OVERLOOK VIEWING SITE}

Viewing Site Guide

Existing

Proposed

Bird Checklist
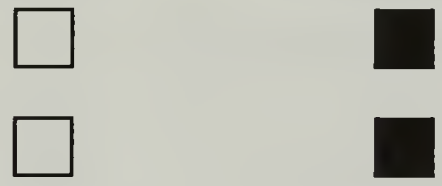

Included in "State Viewing Guide"
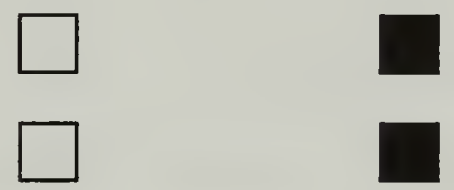

Highway/Roadway Directional Signing
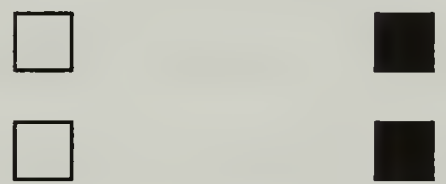

Entrance Sign \#
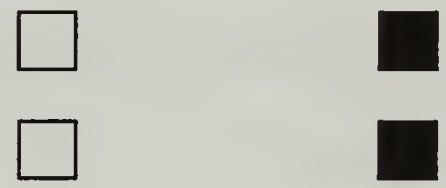

Interpretive Panels *
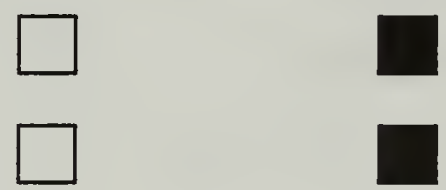

Kiosk *
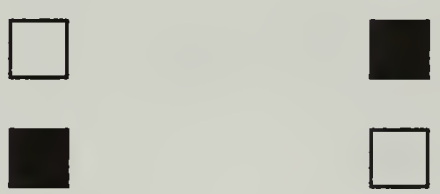

Kiosk \#
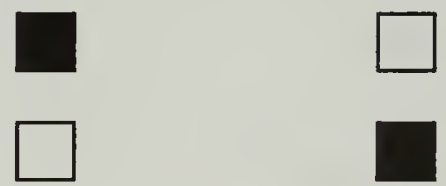

Interpretive Trail \#
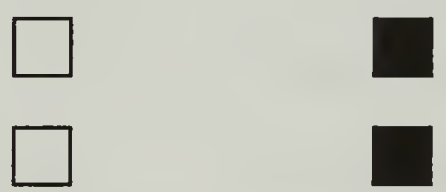

Parking Area \#
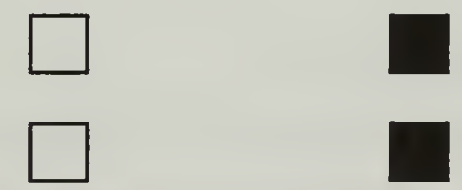

* At Osborne Overlook.

\# Microphyll woodland/wash viewing site. 


\section{AMARGOSA CANYON \\ VIEWING SITE}

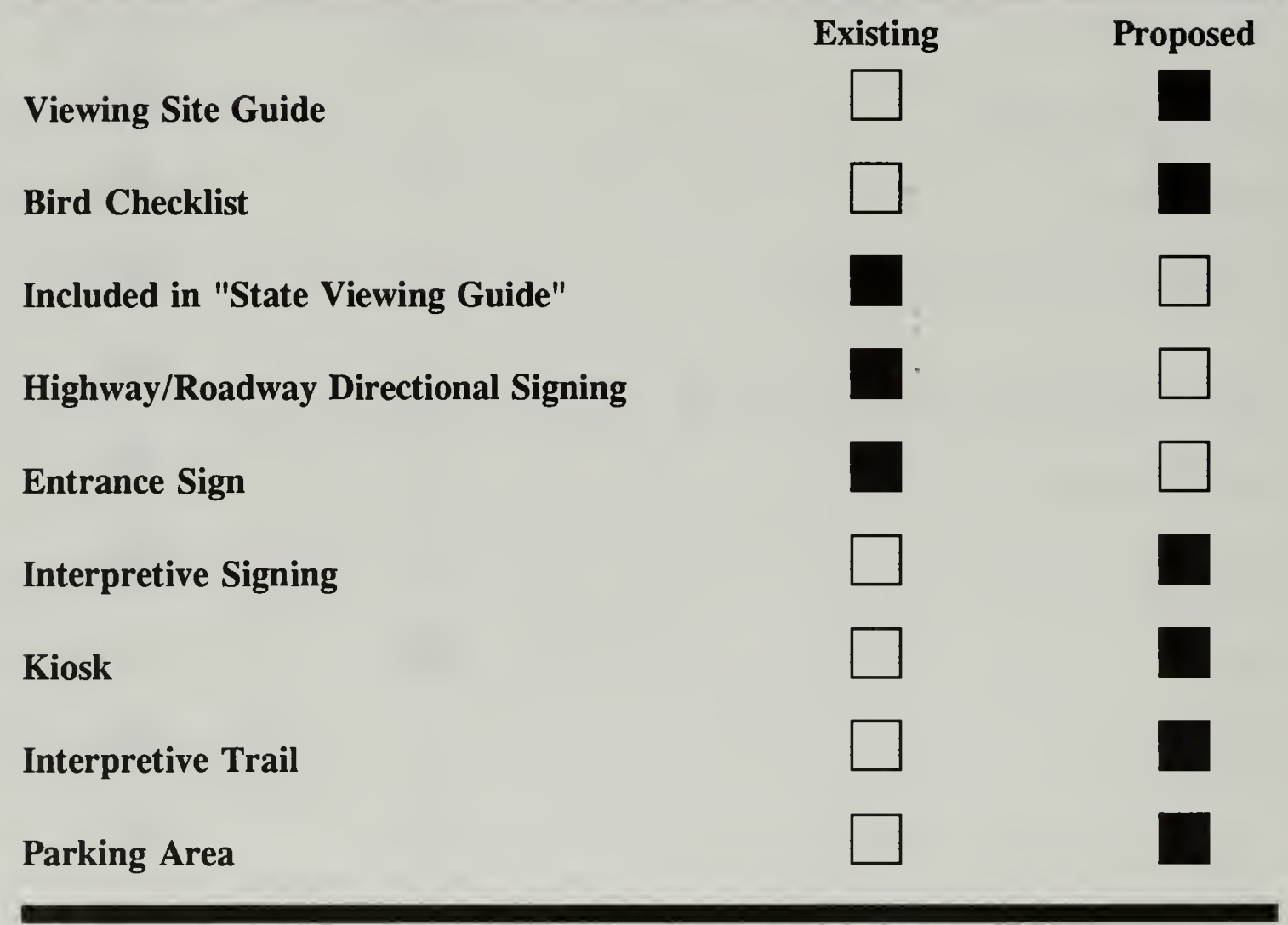

This site is included in the California Wildlife Viewing Guide (Clark 1992); it is listed as Site 149, "Amargosa Canyon/Grimshaw Lake." 


\section{BIG MORONGO CANYON RESERVE VIEWING SITE}

Viewing Site Guide

Existing

Proposed

Bird Checklist
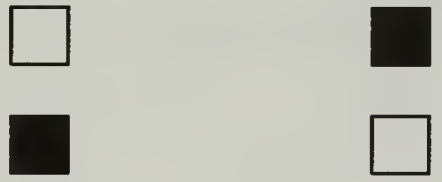

Included in "State Viewing Guide"
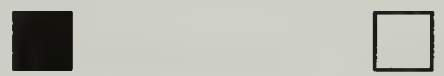

Highway/Roadway Directional Signing
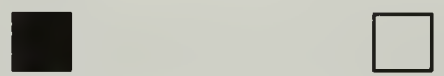

Entrance Sign
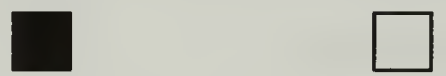

Interpretive Signing
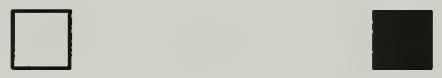

Kiosk
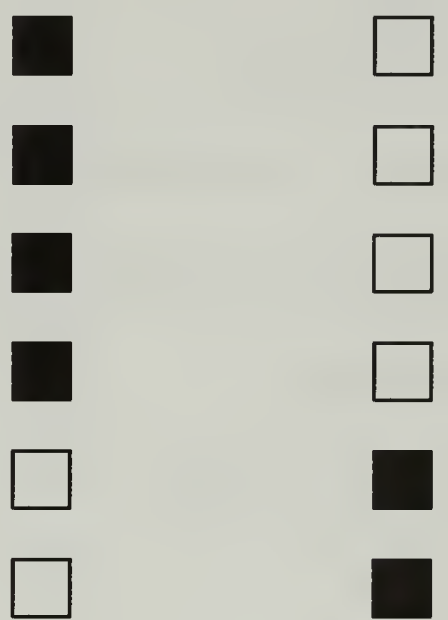

Interpretive Trail
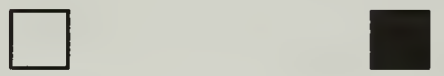

Boardwalk
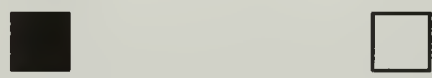

Restrooms
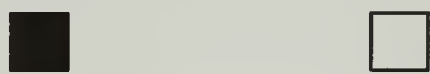

Potable Water
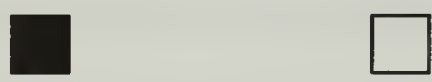

Picnicking Area (at adjacent County Park)

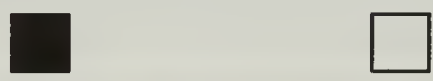

This site is included in the California Wildlife Viewing Guide (Clark 1992); it is listed as Site 143, "Big Morongo Canyon Preserve." The site has a resident caretaker who maintains bird feeders, also. 


\section{COACHELLA VALLEY PRESERVE \\ VIEWING SITE}

Viewing Site Guide

Existing

Proposed

Bird Checklist
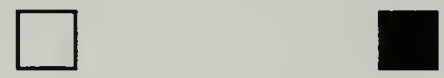

Included in "State Viewing Guide"
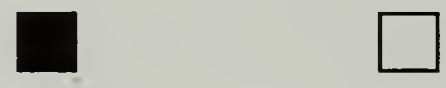

Highway/Roadway Directional Signing
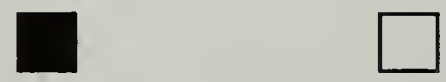

Entrance Sign
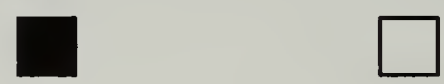

Interpretive Signing
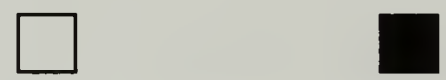

Kiosk
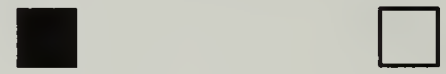

Interpretive Trail
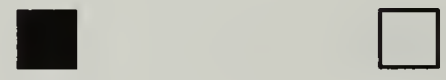

Guided Tours (Spring only)
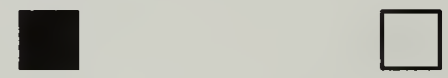

Restrooms
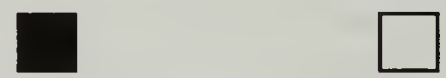

This site is included in the California Wildlife Viewing Guide (Clark 1992); it is listed as Site 141, "Coachella Valley Preserve." The site has an interpretive naturalist. 


\section{DESERT TORTOISE NATURAL AREA VIEWING SITE}

Viewing Site Guide

Bird Checklist

Existing

Proposed

Included in "State Viewing Guide"
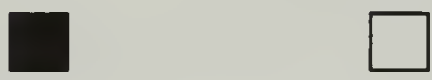

Highway/Roadway Directional Signing
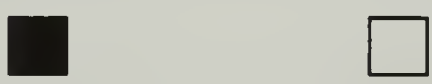

Entrance Sign
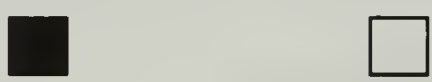

Interpretive Signing
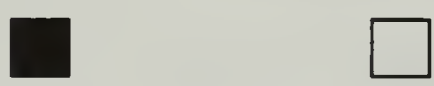

Kiosk
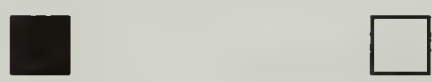

Interpretive Trail
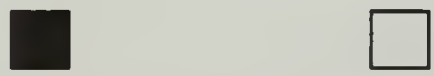

Parking Area
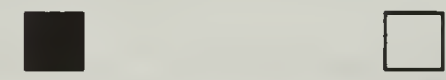

This site is included in the California Wildlife Viewing Guide (Clark 1992); it is listed as Site 146, "Desert Tortoise Natural Area." The site has an interpretive naturalist in the Spring. 


\section{DOS PALMAS RESERVE \\ VIEWING SITE}

Viewing Site Guide

Existing

Proposed

Bird Checklist
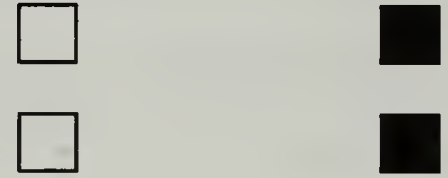

Included in "State Viewing Guide"
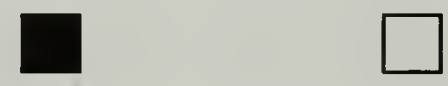

Highway/Roadway Directional Signing
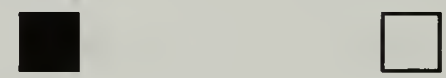

Entrance Sign
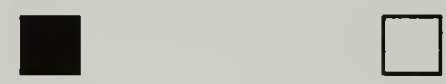

Interpretive Signing
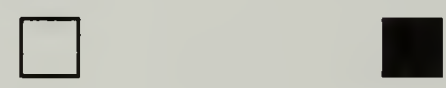

Entrance Kiosk
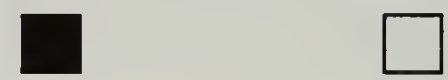

Other Kiosk(s)
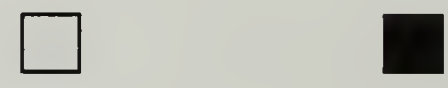

Interpretive Trail
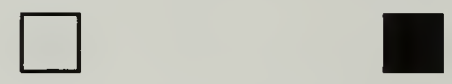

Elevated Viewing Platform
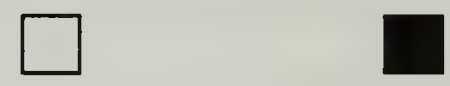

Restrooms
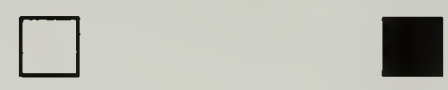

Potable Water
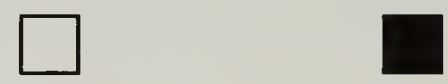

Picnicking Area
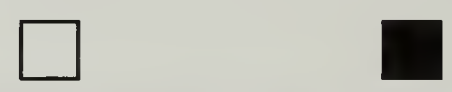

This site is included in the California Wildlife Viewing Guide (Clark 1992); it is listed as Site 139, "Dos Palmas Preserve." The site has a resident caretaker who maintains bird feeders. 


\section{GRIMSHAW LAKE AND MARSH VIEWING SITE}

Existing

Viewing Site Guide

Bird Checklist

Included in "State Viewing Guide"

Highway/Roadway Directional Signing

Entrance Sign

Interpretive Signing

Kiosk

Interpretive Trail

Boardwalk with Elevated Viewing Platform

Bench with Sunshade

Restrooms (at nearby County facilities)

Camping Sites (at nearby County facilities)

Potable Water (at nearby County facilities)
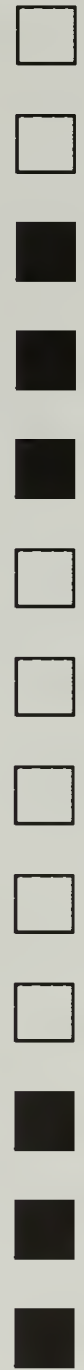

Proposed
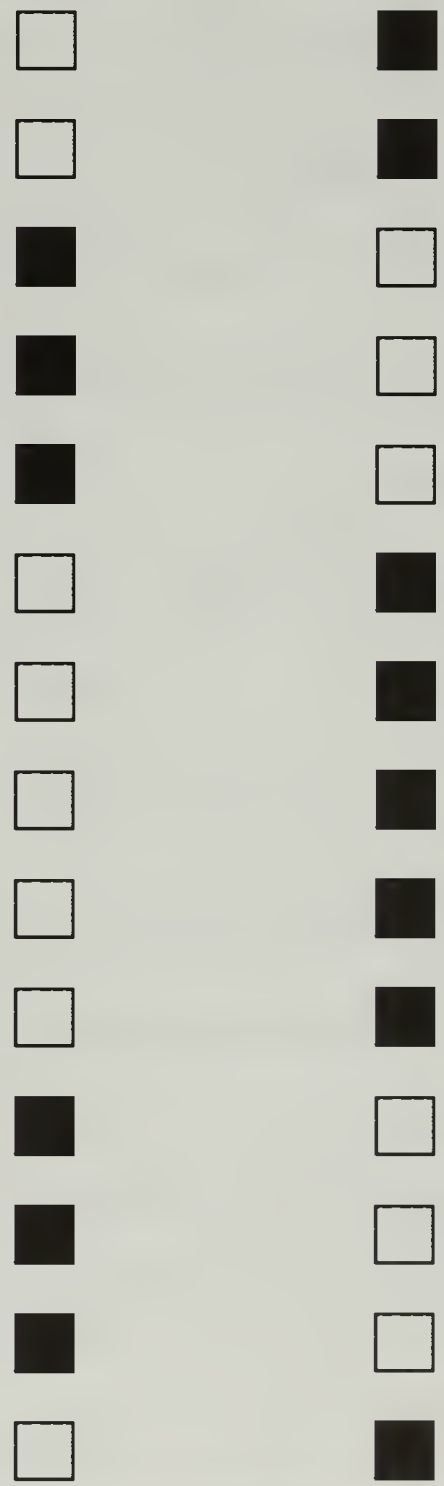

This site is included in the California Wildlife Viewing Guide (Clark 1992); it is listed as Site 149, "Amargosa Canyon/Grimshaw Lake." 


\section{HARPER DRY LAKE AND MARSH VIEWING SITE}

Viewing Site Guide

Existing

Proposed

Bird Checklist
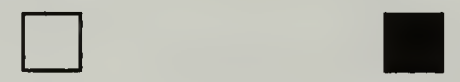

Included in "State Viewing Guide"
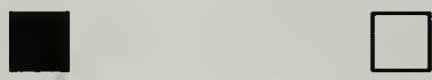

Highway/Roadway Directional Signing
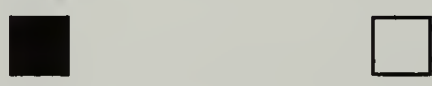

Entrance Sign
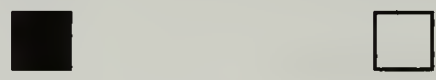

Interpretive Signing
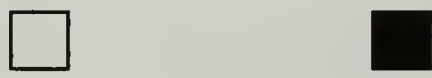

Kiosk
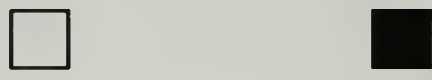

Interpretive Trail
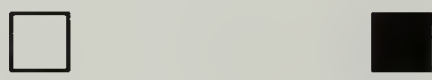

Boardwalk with Elevated Viewing Platform
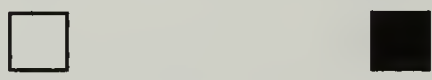

Two Sets of Benches with Sunshades
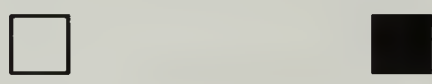

Parking Area
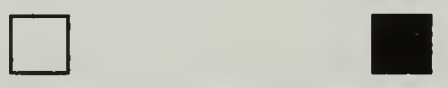

This site is included in the California Wildlife Viewing Guide (Clark 1992); it is listed as Site 147, "Harper Lake." 


\section{SODA SPRINGS \\ VIEWING SITE}

Viewing Site Guide

Existing

Proposed

Bird Checklist
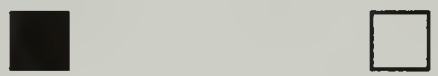

Included in "State Viewing Guide"
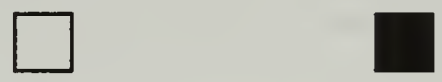

Highway/Roadway Directional Signing
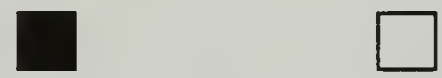

Entrance Sign
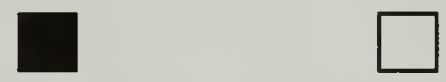

Interpretive Signing
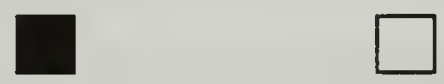

Kiosk
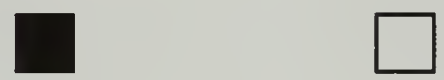

Interpretive Trail
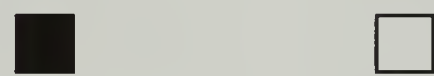

Concrete Viewing Platform
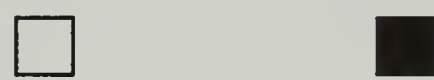

Two Sets of Benches with Sunshades
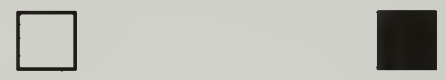

Restrooms
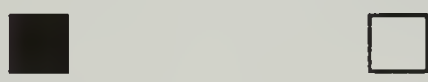

Parking Area
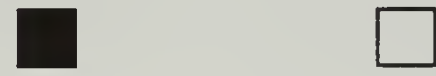

Potable Water
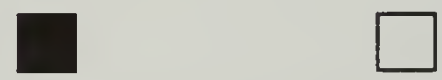

Picnicking Area 


\section{PROGRAM COORDINATION}

The Watchable Wildlife Program is a nationwide initiative. It was initiated in 1988, when the BLM and other agencies and organizations developed a wildlife viewing guide for Oregon. Based on this model, the Defenders of Wildlife launched an effort to extend the program nationwide. As a result of these efforts, a National Memorandum of Understanding (MOU) was signed in 1990. Federal agencies signing the MOU included the BLM, the Bureau of Reclamation, the National Park Service, the U. S. Fish and Wildlife Service, the U. S. Forest Service, and four agencies in the Department of Defense. The MOU was also signed by the Defenders of Wildlife, the International Association of Fish and Wildlife Agencies, the Izaak Walton League of America, the National Audubon Society, and the National Wildlife Federation.

In April 1991, Sara Vickerman, the Regional Program Director for Defenders of Wildlife, prepared a program guide entitled "Watchable Wildlife: A National Initiative." (Vickerman 1991) In 1992 Defenders of Wildlife prepared a guidebook for enhancing wildlife viewing areas (Hudson 1992).

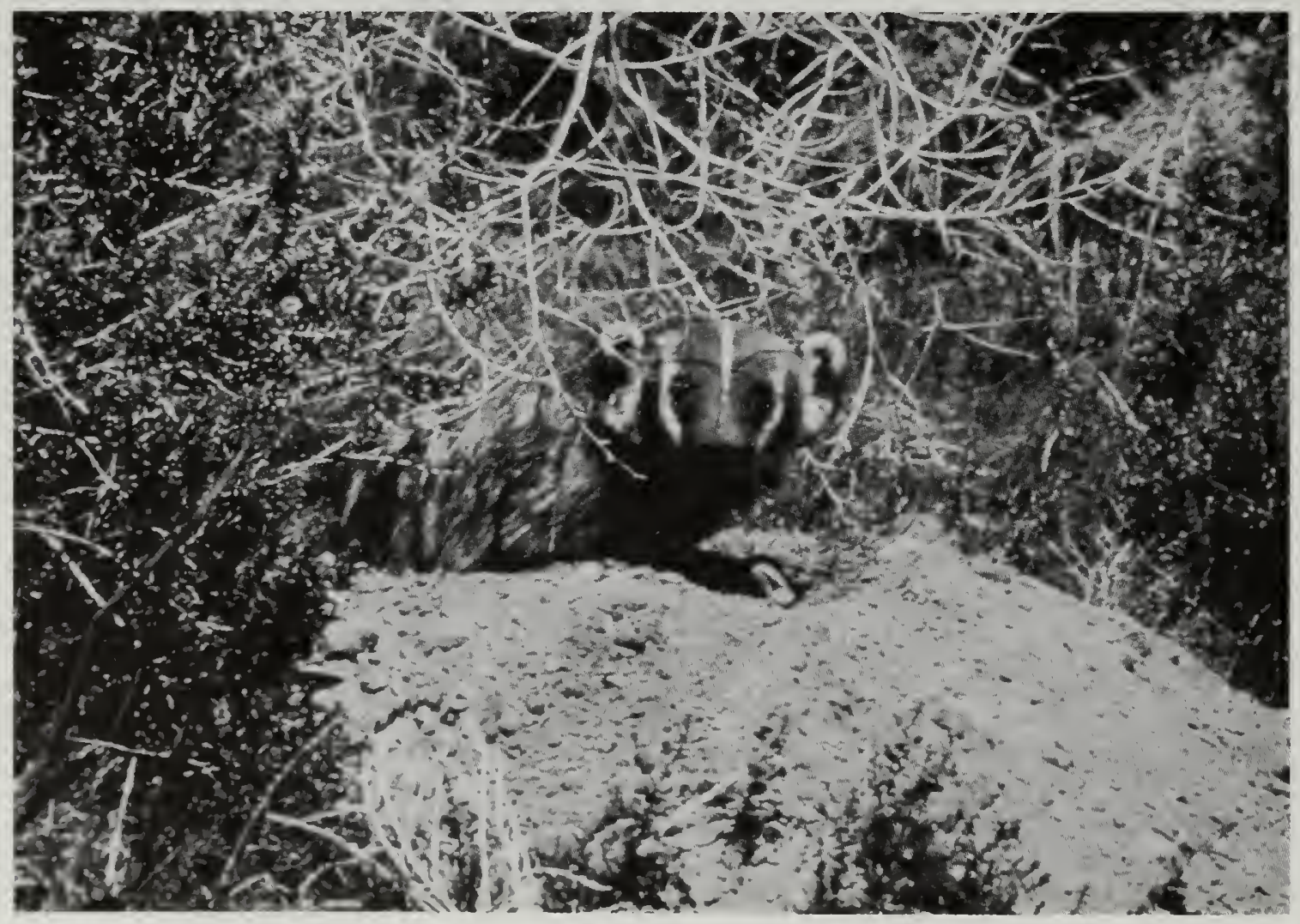


Each state is preparing a state wildlife viewing guide. These guides will be inexpensive, high quality books providing descriptions of the most important viewing sites in the state. The "California Wildlife Viewing Guide" (Clark 1992) was published in 1992. The guide describes six BLM sites in the California Desert District.

As a part of the nationwide network, standard roadway signs indicating a wildlife viewing site were developed. The "binocular" signs are to be placed on major arteries and minor roadways leading to each viewing site. In California, CALTRANS has agreed to produce and erect these signs on State and Federal highways. Coordination is underway to recruit the county road departments to place signs on county-maintained roads. The California Desert District has purchased signs for use at the viewing sites described in this plan.

In California a Watchable Wildlife State Coordinating Committee was formed to promote and coordinate the statewide effort. The California Desert District has designated a District Watchable Wildlife Coordinator and established a District Office Team to coordinate the evaluation of proposed sites and review site enhancement plans. Each wildlife viewing site shall have a team assigned to prepare a detailed site enhancement plan.

For many of the California Desert District viewing sites, partnerships have been developed with other organizations. The following table shows some of the cooperators for each viewing site. Other cooperators may become involved in various aspects. For example, local chapters of the Audubon Society might be recruited to prepare bird checklists for sites not having them.

Among the assistance given at the various sites are the funding of study contracts (e.g., U. S. Fish and Wildlife Service through "Section 6", the Department of Fish and Game through California Environmental License Plate program and Energy Resources Fund program); the providing of caretakers (e.g., at Big Morongo and Dos Palmas by The Nature Conservancy and at Soda Springs by the Desert Studies Consortium); the providing of on-site naturalists (e.g., the Desert Tortoise Natural Area by the Desert Tortoise Preserve Committee); the publishing of bird checklists (e.g., Big Morongo by The Nature Conservancy); the construction of viewing improvements, interpretive facilities, and visitor service facilities; and placement of signs.

The development of partnerships is an essential element of the Watchable Wildlife Program. These partnerships are not only necessary in accomplishing the planned enhancements, but also in furthering the public education and involvement goals of the program. 
LIST OF HISTORIC COOPERATORS AT EACH VIEWING SITE

Afton Canyon

Algodones Dunes - Osborne Overlook

Amargosa Canyon

Big Morongo Preserve

Coachella Valley Preserve

Desert Tortoise Natural Area

Dos Palmas Reserve

Grimshaw Lake and Marsh

Harper Dry Lake and Marsh

Soda Springs
State Department of Fish and Game

State Off-Highway Vehicle Commission

State Department of Fish and Game The Nature Conservancy

The Nature Conservancy

The County of San Bernardino

The Nature Conservancy

State Department of Fish and Game

U. S. Fish and Wildlife Service

Desert Tortoise Preserve Committee Desert Tortoise Council

The Nature Conservancy

State Department of Fish and Game

The Nature Conservancy

State Department of Fish and Game

State Lands Commission

State Department of Parks and Recreation U. S. Fish and Wildlife Service

State Department of Fish and Game U. S. Fish and Wildlife Service

State Department of Fish and Game

Desert Studies Consortium

State Department of Fish and Game U. S. Fish and Wildlife Service 


\section{FUNDING REQUIREMENTS}

Following are tables showing the estimated costs for developing and maintaining the viewing site enhancements (i.e., printed materials, signs, and facilities). These costs are presented for long-range planning purposes only. No implementation cost is presented for enhancements which have been completed.

\section{AFTON CANYON VIEWING SITE}

\begin{tabular}{lcc}
\hline & $\begin{array}{c}\text { Development } \\
\text { cost } \\
(\$ 000)\end{array}$ & $\begin{array}{c}\text { Ave. annual } \\
\text { maint. cost } \\
(\$ 000)\end{array}$ \\
\hline Prepare site enhancement plan and EA & 4 & - \\
Prepare and print Viewing Site Guide & 1 & 0.1 \\
Prepare and print bird checklist & 2 & 0.1 \\
Maintain directional signs & - & 0.3 \\
Maintain entrance sign & - & 0.1 \\
Prepare and erect interpretive signs & 3 & 0.8 \\
Design and construct kiosk & 5 & 0.2 \\
Construct interpretive trail & 5 & 0.2 \\
Maintain and manage restrooms & - & 0.4 \\
Manage potable water & - & 0.5 \\
Maintain campsites & - & 2.0 \\
Maintain Picnicking area & - & 0.4 \\
TOTAL & 20 & 5.1 \\
\hline
\end{tabular}




\section{ALGODONES DUNES-OSBORNE OVERLOOK VIEWING SITE}

\section{Development \\ cost \\ (\$000)}

Ave annual

maint. cost

(\$000)

Prepare site enhancement plan and EA

Prepare and print Viewing Site Guide

Prepare and print bird checklist

Maintain directional signs

Prepare and erect entrance sign

Construct interpretive panels *

Maintain kiosk *

Construct kiosk

Construct interpretive trail

Construct and maintain parking area

TOTAL

\section{AMARGOSA CANYON VIEWING SITE}

Development
cost
$(\$ 000)$

$(\$ 000)$

Prepare site enhancement plan and EA

Prepare and print Viewing Site Guide

Prepare and print bird checklist

Maintain directional signs

Maintain entrance sign

Prepare and erect interpretive sign(s)

Design and construct kiosk

Construct interpretive trail

Parking Area

TOTAL
4

1

2

-

-

3

5

10

5

30
Ave. annual maint. cost (\$000) 


\section{BIG MORONGO VIEWING SITE}

\begin{tabular}{lcc}
\hline & $\begin{array}{c}\text { Development } \\
\text { cost } \\
(\$ 000)\end{array}$ & $\begin{array}{c}\text { Ave. annual } \\
\text { maint. cost } \\
(\$ 000)\end{array}$ \\
\hline Prepare site enhancement plan and EA & 4 & - \\
Prepare and print Viewing Site Guide & 1 & 0.1 \\
Print bird checklist * & - & - \\
Maintain directional signs & - & 0.1 \\
Prepare and erect entrance sign & 2 & 0.1 \\
Prepare and erect interpretive signs & 3 & 0.1 \\
Design and construct kiosk & 7 & 0.3 \\
Construct interpretive trail & 5 & 0.4 \\
Construct and maintain boardwalk ** & - & - \\
Maintain and manage restrooms and potable water ** & - & - \\
Maintain picnicking area *** & - & - \\
TOTAL & 22 & $\mathbf{1 . 1}$ \\
\hline
\end{tabular}

* Supplied by San Bernardino Chapter of Audubon Society.

** Maintained by The Nature Conservancy on their property.

*** Available at adjacent County Park.

\section{COACHELLA VALLEY PRESERVE VIEWING SITE}

\begin{tabular}{cc}
\hline Development & cost \\
$(\$ 000)$ & maint. cost \\
$(\$ 000)$
\end{tabular}

Prepare site enhancement plan and EA

Prepare and print Viewing Site Guide

Prepare and print bird checklist

4

Maintain directional signs

1

2

0.1

Maintain entrance sign *

Prepare and erect interpretive signs

$-$

0.1

Maintain kiosk *

Maintain interpretive trail

Maintain and manage restrooms *

Manage potable water *

Maintain and manage picnicking area *

TOTAL

* Maintained by The Nature Conservancy on their property. 
DESERT TORTOISE NATURAL AREA VIEWING SITE

Development
cost
$(\$ 000)$

Ave. annual maint. cost (\$000)

Prepare site enhancement plan and EA

Prepare and print Viewing Site Guide

Prepare and print bird checklist

Maintain directional signs

Maintain entrance sign

Maintain interpretive signs

Maintain kiosk

Maintain interpretive trail

Guided tours (Spring only) *

Maintain and manage restrooms

Maintain parking area

4

1

2

0.1

0.1

0.3

0.3

0.3

0.3

0.4

0.5

0.5

TOTAL

* Naturalist furnished by Desert Tortoise Preserve Committee.

\section{DOS PALMAS RESERVE VIEWING SITE}

\begin{tabular}{ccc}
\hline & $\begin{array}{c}\text { Development } \\
\text { cost } \\
(\$ 000)\end{array}$ & $\begin{array}{c}\text { Ave. annual } \\
\text { maint. cost } \\
(\$ 000)\end{array}$ \\
& & $(\$ 2)$ \\
\hline
\end{tabular}

Prepare site enhancement plan and EA

Prepare and print Viewing Site Guide

Prepare and print bird checklist

4

0.1

Maintain directional signs

Maintain entrance sign

Prepare and erect interpretive signs

Maintain kiosk

Construct interpretive trail

Construct elevated viewing platform

Construct restrooms for public use

Install potable water system for public use

Design and construct picnicking area

TOTAL

\section{3}

$-$

$-$

6

$-$

7

20

20

3

5

69
0.1

0.1

0.4

0.5

0.3

0.6

1.0

1.0

0.5

0.4

5.0

* Maintained by The Nature Conservancy on their property. 


\section{GRIMSHAW LAKE AND MARSH VIEWING SITE}

\begin{tabular}{lcc}
\hline & $\begin{array}{c}\text { Development } \\
\text { cost } \\
(\$ 000)\end{array}$ & $\begin{array}{c}\text { Ave. annual } \\
\text { maint. cost } \\
\text { (\$000) }\end{array}$ \\
\hline Prepare site enhancement plan and EA & 4 & - \\
Prepare and print Viewing Site Guide & 1 & 0.1 \\
Print bird checklist & 2 & 0.2 \\
Maintain directional signs & - & 0.2 \\
Maintain entrance sign & - & 0.1 \\
Prepare and erect interpretive signs & 4 & 0.6 \\
Design and construct kiosk & 7 & 0.3 \\
Construct interpretive trail & 5 & 0.4 \\
Construct boardwalk with elevated viewing platform & 30 & 1.0 \\
Construct bench with sunshade & 2 & 0.2 \\
Maintain and manage restrooms * & - & - \\
Maintain and manage camping sites * & - & - \\
Maintain and manage potable water * & - & - \\
Construct parking area & 4 & 0.4 \\
TOTAL & 59 & 3.5 \\
\hline
\end{tabular}

Available at nearby County facilities.

HARPER DRY LAKE AND MARSH VIEWING SITE

\begin{tabular}{lcc}
\hline & $\begin{array}{c}\text { Development } \\
\text { cost } \\
(\$ 000)\end{array}$ & $\begin{array}{c}\text { Ave. annual } \\
\text { maint. cost } \\
(\$ 000)\end{array}$ \\
\hline Prepare site enhancement plan and EA & 4 & - \\
Prepare and print Viewing Site Guide & 1 & 0.1 \\
Prepare and print bird checklist & 2 & 0.1 \\
Maintain directional signs & - & 0.3 \\
Maintain entrance sign & - & 0.1 \\
Prepare and erect interpretive sign(s) & 3 & 0.8 \\
Design and construct kiosk & 5 & 0.2 \\
Construct interpretive trail & 5 & 0.4 \\
Construct two sets of benches with sunshades & 4 & 0.4 \\
Construct parking area & 2 & 0.2 \\
TOTAL & & 2.6 \\
\hline
\end{tabular}


SODA SPRINGS VIEWING SITE

\begin{tabular}{lcc}
\hline & $\begin{array}{c}\text { Development } \\
\text { cost } \\
(\$ 000)\end{array}$ & $\begin{array}{c}\text { Ave. annual } \\
\text { maint. cost } \\
(\$ 000)\end{array}$ \\
\hline $\begin{array}{l}\text { Prepare site enhancement plan and EA } \\
\text { Prepare and print Viewing Site Guide }\end{array}$ & 4 & - \\
Print bird checklist & 1 & 0.1 \\
Maintain directional signs & - & 0.1 \\
Maintain entrance sign & - & 0.2 \\
Maintain interpretive signs & - & 0.1 \\
Maintain kiosk & - & 0.1 \\
Lengthen and maintain interpretive trail & - & 0.5 \\
Construct concrete viewing platform & 5 & 0.4 \\
Construct two sets of benches with sunshades & 5 & 0.2 \\
Maintain restrooms & 4 & 0.4 \\
Maintain parking area & - & 0.5 \\
Maintain picnicking area & - & 0.3 \\
Manage potable water system * & - & 0.2 \\
TOTAL & - & - \\
\hline * Maintained by Desert Studies Consortium & 19 & 3.1 \\
\hline
\end{tabular}

* $\quad$ Maintained by Desert Studies Consortium.

\section{REFERENCES}

BLM. 1992. Watchable Wildlife Strategic Plan. BLM Rept. No. BLM/WO/PT91/005+4351. 19pp.

Clark, J. L. 1992. California Wildlife Viewing Guide. Falcon Press, Helena, Montana. 159pp.

Hudson, W. E. (Ed.) 1992. Nature Watch. Falcon Press, Helena, Montana. 199pp.

Vickerman, S. 1991. Watchable Wildlife: A National Initiative. Defenders of Wildlife, Portland, Oregon. 86pp. 



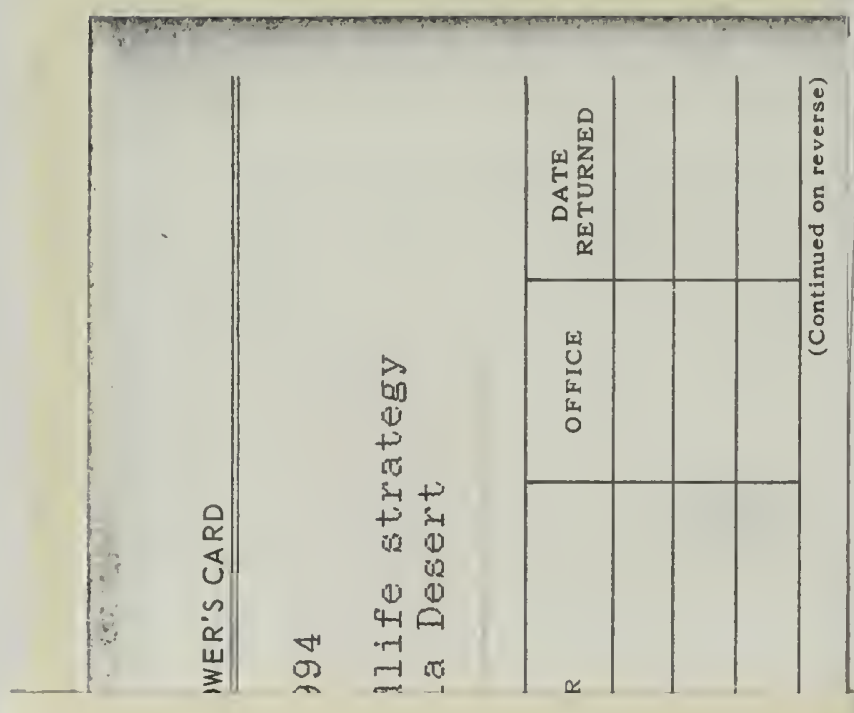

\section{BLM LIBRARY}

SC-653, BLDG. 50

DENVER FEDERAL CENTER

P. O BOX 25047

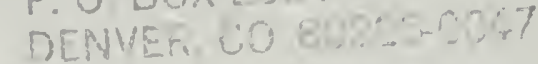

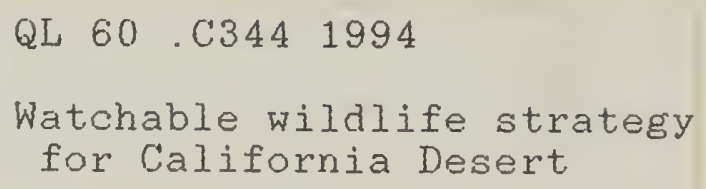




\section{BLM LIBRARY}

SC-653, BLDG. 50

DENVER FEDERAL CENTER

P. O. BOX 25047

DENVER, CO 80225-0047 


\section{California Desert District Fish and Wildlife 2000 Strategy Series}

Topic

Watchable Wildlife Strategy

Special Status Fishes Strategy

Upland Game Bird Habitat

Management Strategy

Raven Management Strategy

Neotropical (Non-game)

Bird Strategy

Special Status Plants Strategy

Wetland/Riparian Habitát

Management Strategy

Raptor Habitat Management Strategy

Deer Habitat Management Strategy

Plant Sales and Salvage Strategy
Availability

January 1994

In preparation

In preparation

In preparation

Planned

Planned

Planned

Planned

Planned

Planned

Those strategies which are completed are available at the following address:

California Desert District

6221 Box Springs Blvd.

Riverside, CA 92509 